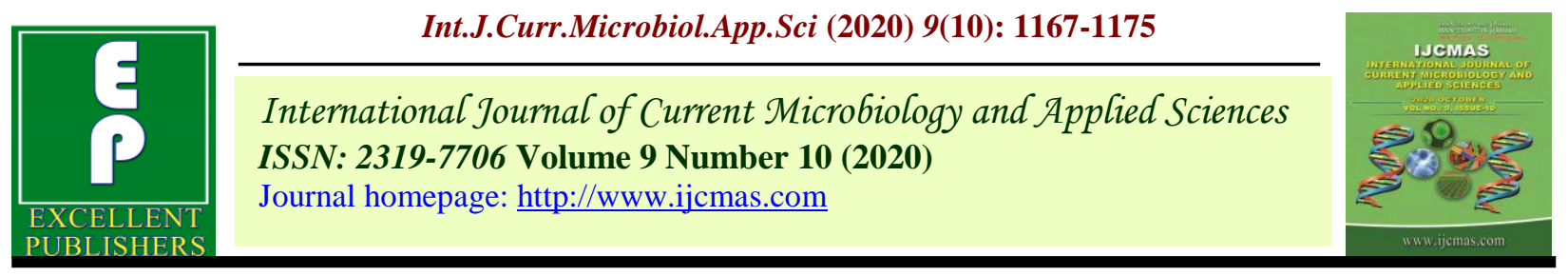

\title{
Effect of Integrated Nutrient Management on Nutrient Uptake, Physico-Chemical Properties of Soil and Economics of Hybrid Rice
}

\author{
Thalesh Kumar ${ }^{1}$, A. K. Thakur ${ }^{1 *}$, Sandeep Kumar ${ }^{1}$, \\ Om Prakash Bhaskar ${ }^{1}$ and Bhupendra Kumar ${ }^{2}$
}

${ }^{1}$ Department of Agronomy and Soil Science and ${ }^{2}$ Agricultural Chemistry, SG College of Agriculture and Research Station, Jagdalpur, Indira Gandhi Krishi Vishwavidyalaya Raipur

*Corresponding author

\section{A B S T R A C T}

\begin{tabular}{l} 
Ke y w o r d s \\
NPK uptake, Soil \\
physic-chemical \\
properties, \\
Economics \\
Article Info \\
$\begin{array}{l}\text { Accepted: } \\
\text { 10 September } 2020 \\
\text { Available Online: } \\
10 \text { October } 2020\end{array}$ \\
\hline
\end{tabular}

\begin{abstract}
A field experiment was conducted during Kharif season of 2018 in Alfisols to study grain yield of hybrid rice varieties as influenced integrated nutrient management. Results revealed that V1 (IRH-103) found significantly highest N, P and $\mathrm{K}$ contain in grain and straw of than V2 (IRH-111) and in different nutrient management N5 (150\% RDF through inorganic) was observed significantly higher $\mathrm{N}, \mathrm{P}$ and $\mathrm{K}$ contain in grain and straw. No significant differences were found in available NPK, pH, Ec, OC and BD after harvest in soil in variety V1 (IRH-103) and V2 (IRH-111) but in case of different nutrient management practices N5 (150\% RDF) observed significantly highest available NPK, pH, $\mathrm{Ec}, \mathrm{OC}$ and $\mathrm{BD}$ after harvested in soil which was found on par with N4 (150\% RDF through organic + inorganic). V1 (IRH 103) recorded significantly higher economic yield and monetary return than the variety V2 (IRH-111) and in different nutrient management practices N5 (150\% RDF through inorganic) found significantly higher economic yield and monetary return among all the integrated nutrient management treatments.
\end{abstract}

\section{Introduction}

Rice is the most important and widely cultured food crop, which supply half of the everyday food for one of every three people on the earth (Mahmud et al., 2016). India is the second most populous nation and the major producer of paddy in the world after China (FAOSTAT, 2014). In India, rice occupies an area of 43.39 mha with production and productivity of $104.32 \mathrm{mt}$ and $2.4 \mathrm{t} \mathrm{ha}^{-1}$ respectively. Uttar Pradesh occupies an area 5.87 mha which is highest rice area among the all states, while highest rice production was reported in West Bengal with $15.75 \mathrm{mt}$. and Punjab has highest average productivity with $3.9 \mathrm{t} \mathrm{ha}^{-1}$. In Chhattisgarh, rice occupies an area of 3.84 mha with production and productivity of $6.09 \mathrm{mt}$ and $1.5 \mathrm{tha}^{-1}$, respectively (Ministry of agriculture $\&$ farmer's welfare, 2016).

The hybrid cultivars are highly responsive to higher doses of nutrients and thereby the high yield potentiality (Yang L. P., 1996). Rice hybrids generally produce yield higher than 
conventional self-pollinating rice varieties because of higher phenological yield attributes like panicle number per unit area and more grains panicle ${ }^{-1}$ (Peng et al., 2002). About 10 to $15 \%$ increase in rice yields is possible due to development of rice hybrids for the tropical countries (Virmani, 1996). In India the yield of the present high-yielding rice varieties has reached a plateau and plant types with higher yield potential are now needed to overcome this yield stagnation and meet out the demands of the ever increasing population (Singh et al., 2004).

Modern chemical based agricultural practices have led to several new challenges, viz., declining productivity, deteriorating of soil and water resources, diminishing biodiversity and increase in environmental pollution. High nitrogenous fertilizer application without appropriate balance with phosphorus, potassium and other nutrients resulted harmful effect on soil (Kumar et al., 2011).

Under such situations organic source of nutrient with suitable combination of inorganic nutrient management has significant role in improving productivity of crop as well as improve the physical and chemical properties of soil. Vermicompost application on the soil is considered a good management practice in agricultural production system due to the increase of soil microbial growth and activity, subsequently increased mineralization of plant nutrients and enhance soil fertility and quality of soil (Arancon et al., 2006).

Uptake of N, P and $\mathrm{K}$ in rice grain and straw showed that application of recommended dose of NPK with the manure fertilizer would maximize the uptake of nutrients than the application of recommended levels of fertilizers alone (Jagadeswari and Kumaraswamy, 2000).

\section{Materials and Methods}

The experiment was conducted in Instructional cum Research Farm SG College of Agriculture and Research Station, Jagdalpur, Chhattisgarh. The experiment was laid out in Split plot design with 2 main plot viz V1- IRH 103, and V2- IRH 111 and subplot treatment was in 5 level i.e. 100\% RDF through inorganic (N1), $75 \%$ RDF through inorganic + organic (N2), 100\% RDF through inorganic + organic (N3), $150 \%$ RDF through inorganic + organic (N4) and 150\% RDF through inorganic (N5) which was replicated in thrice. Treatment N2, N3 and N4 had $2 \mathrm{q} \mathrm{ha}^{-1}$ Vermicompost $+25 \mathrm{~kg} \mathrm{ha}^{-1}$ DAP were applied at 25-30 DAT. The recommended dose of fertilizer was 120:60:40 kg N: P: $\mathrm{K} \mathrm{ha}^{-1}$ applied as per treatment. However, after crop harvesting the soil sample from trial field was analyzed for determination of soil physico-chemical properties and the measured data were subjected to analysis of variance (ANOVA) and their means was separated using Gomez and Gomez at 5\% level of significance. The soil of the experimental site was characterized as silty loam (Alfisols) which is locally known as Mal. It comes under midland situation of landscape of Jagdalpur and soil was slightly acidic in reaction with high to medium in fertility level. A total $1085 \mathrm{~mm}$ rainfall was received during the cropping season. During the experimentation maximum and minimum temperature was ranges between 26.8 and $37.2{ }^{\circ} \mathrm{C}$ and 8.7 to $24.3{ }^{\circ} \mathrm{C}$ respectively.

\section{Results and Discussion}

\section{$\mathrm{N}, \mathrm{P}$ and $\mathrm{K}$ content}

Nitrogen contains of grain and straw as influenced by different treatments are presented in Table 1. The data reveals that there was no significant difference of $\mathrm{N}$ contain in grain and straw in variety V1 (IRH 
103) and V2 (IRH 111), but in case of different nutrient management practices treatment N5 (150\% RDF through inorganic) observed significantly highest $\mathrm{N}$ contain in grain and straw which was at par with treatment N4 $(150 \%$ RDF through organic + inorganic) and lowest $\mathrm{N}$ content was noticed in treatment $\mathrm{N} 2$ (75\% RDF through organic + inorganic). More nitrogen content was found in grain and straw may be due to good root proliferation, more number of tillers and high photosynthesis.

$\mathrm{P}$ contains of grain and straw is presented in Table 1. The data reveals that there was no significant difference was found in $\mathrm{P}$ contain in grain and straw in both variety V1 (IRH 103) and V2 (IRH 111) but in different nutrient management practices treatment $\mathrm{N} 5$ (150\% RDF through inorganic) observed significantly highest $\mathrm{P}$ contain in grain and straw which was observed on par with treatment N4 $(150 \%$ RDF through organic + inorganic) and lowest $\mathrm{P}$ content was noticed in treatment $\mathrm{N} 2(75 \% \mathrm{RDF}$ through organic + inorganic). Treatment contain more phosphorus due to $150 \%$ RDF through inorganic supply more phosphorus to plant and increase high grain and straw yield.

$\mathrm{K}$ contain of grain and straw presented in Table 1. The data shows that there were no significant differences was observed in $\mathrm{K}$ contain in grain and straw in both variety $\mathrm{V} 1$ (IRH 103) and V2 (IRH 111) and in different nutrient management practices N5 (150\% RDF through inorganic) observed significantly highest $\mathrm{K}$ contain in grain and straw but which was at par with treatment N4 (150\% RDF through organic + inorganic) and lowest $\mathrm{K}$ contain was noticed in treatment N2 (75\% RDF through organic + inorganic). Similar result was also observed by Mahmud et al., (2016) he reported the maximum nitrogen, phosphorus \& potassium content in grain $1.192 \%, 0.287 \% \& 0.474 \%$ respectively with vermicompost $4 \mathrm{tha}^{-1}+150-24-99-18$ $\mathrm{kg} \mathrm{N}, \mathrm{P}, \mathrm{K}, \mathrm{S} \mathrm{ha}^{-1}$.

\section{N, P and K uptake}

Nitrogen uptake in grain and straw is presented in Table 2 . The data reveals that the V1 (IRH 103) showed significantly highest N uptake in grain and straw than V2 (IRH 111). However in case of different nutrient management practices treatment N5 (150\% RDF through inorganic) observed significantly highest $\mathrm{N}$ uptake in grain and straw, while lowest $\mathrm{N}$ uptake in grain and straw was noticed in treatment N3 $(100 \%$ $\mathrm{RDF}$ through organic + inorganic) and $\mathrm{N} 2$ (75\% RDF through organic + inorganic) respectively. Similar result was also found by Paul et al., (2013) he reported the highest nitrogen uptake by grain with $\mathrm{N} 180, \mathrm{P} 80$, $\mathrm{K} 40+\mathrm{Znf}+\mathrm{FYM}$ which was significantly higher than all the fertility treatments.

The data on $\mathrm{P}$ uptake in grain and straw is presented in Table 2. The data shows that V1 (IRH 103) observed significantly highest $\mathrm{P}$ uptake in grain and straw than V2 (IRH 111). Whereas, in different nutrient management practices, treatment N5 (150\% RDF through organic + inorganic) observed significantly highest $\mathrm{P}$ uptake in grain and straw, while lowest $\mathrm{P}$ uptake in grain and straw was noticed in treatment N3 (100\% RDF through organic + inorganic).

$\mathrm{K}$ uptake in grain and straw is presented in Table 2. The data reveals that the V1 (IRH 103) showed significantly highest $K$ uptake in grain and straw than V2 (IRH 111). However, in case of different nutrient management practices treatment N5 (150\% RDF through inorganic) observed significantly highest $\mathrm{K}$ uptake in grain and straw, while lowest $\mathrm{K}$ uptake in grain and straw was noticed in treatment N3 (100\% RDF through). 
Table.1 Effect of integrated nutrient management on NPK content in grain and straw of hybrid rice

\begin{tabular}{|c|c|c|c|c|c|c|}
\hline \multirow[t]{3}{*}{ Treatment } & \multicolumn{6}{|c|}{ NPK content (\%) } \\
\hline & \multicolumn{2}{|c|}{$\mathbf{N}$} & \multicolumn{2}{|c|}{$\mathbf{P}$} & \multicolumn{2}{|c|}{$\mathbf{K}$} \\
\hline & Grain & Straw & Grain & straw & Grain & Straw \\
\hline \multicolumn{7}{|c|}{ Varieties } \\
\hline V1 & 1.02 & 0.55 & 0.25 & 0.12 & 0.31 & 1.25 \\
\hline $\mathbf{V 2}$ & 1.02 & 0.55 & 0.25 & 0.12 & 0.31 & 1.22 \\
\hline SEm \pm & 0.002 & 0.004 & 0.004 & 0.002 & 0.004 & 0.02 \\
\hline CD at $5 \%$ & NS & NS & NS & NS & NS & NS \\
\hline CV \% & 3.08 & 5.75 & 12.75 & 8.49 & 10.22 & 5.11 \\
\hline \multicolumn{7}{|c|}{ Integrated Nutrient Management } \\
\hline N1 & 1.02 & 0.53 & 0.25 & 0.11 & 0.30 & 1.21 \\
\hline $\mathbf{N} 2$ & 0.98 & 0.52 & 0.22 & 0.11 & 0.27 & 1.08 \\
\hline N3 & 1.00 & 0.55 & 0.24 & 0.11 & 0.29 & 1.16 \\
\hline N4 & 1.05 & 0.57 & 0.26 & 0.12 & 0.33 & 1.31 \\
\hline N5 & 1.08 & 0.58 & 0.28 & 0.13 & 0.36 & 1.43 \\
\hline SEm \pm & 0.009 & 0.006 & 0.007 & 0.004 & 0.008 & 0.03 \\
\hline CD at $5 \%$ & 0.03 & 0.02 & 0.02 & 0.01 & 0.03 & 0.01 \\
\hline CV \% & 3.08 & 5.75 & 12.75 & 8.49 & 10.22 & 6.26 \\
\hline
\end{tabular}

V1-IRH 103, V2- IRH 111, N1- 100\% RDF (Inorganic), N2-75\% RDF (Organic + inorganic), N3-100\% RDF (Organic + inorganic), N4- 150\% RDF (Organic + inorganic), N5- 150\% RDF (Inorganic)

Table.2 Effect of integrated t nutrient management on Nutrient uptake of hybrid rice

\begin{tabular}{|c|c|c|c|c|c|c|}
\hline \multirow[t]{3}{*}{ Treatment } & \multicolumn{6}{|c|}{ NPK uptake (kg ha' $\left.{ }^{-1}\right)$} \\
\hline & \multicolumn{2}{|c|}{$\mathbf{N}$} & \multicolumn{2}{|c|}{$\mathbf{P}$} & \multicolumn{2}{|c|}{$\mathbf{K}$} \\
\hline & Grain & Straw & Grain & straw & Grain & Straw \\
\hline \multicolumn{7}{|c|}{ Varieties } \\
\hline V1 & 47.81 & 31.50 & 11.58 & 6.71 & 14.61 & 71.67 \\
\hline $\mathbf{V} 2$ & 38.80 & 26.46 & 9.38 & 5.70 & 11.59 & 58.91 \\
\hline SEm \pm & 0.13 & 0.38 & 0.19 & 0.08 & 0.21 & 1.46 \\
\hline CD at $5 \%$ & 0.22 & 2.48 & 1.27 & 0.55 & 1.40 & 9.54 \\
\hline CV \% & 1.13 & 5.06 & 7.14 & 5.24 & 6.33 & 6.70 \\
\hline \multicolumn{7}{|c|}{ Integrated Nutrient Management } \\
\hline N1 & 41.45 & 27.46 & 9.99 & 5.82 & 12.32 & 62.06 \\
\hline $\mathbf{N} 2$ & 41.32 & 26.65 & 9.35 & 5.64 & 11.42 & 55.46 \\
\hline N3 & 40.27 & 28.03 & 9.45 & 5.68 & 11.72 & 59.45 \\
\hline N4 & 44.30 & 29.55 & 11.03 & 6.36 & 13.82 & 67.73 \\
\hline N5 & 49.18 & 33.22 & 12.59 & 7.54 & 16.23 & 81.75 \\
\hline SEm \pm & 1.49 & 1.18 & 0.44 & 0.35 & 0.49 & 2.52 \\
\hline CD at $5 \%$ & 4.5 & 3.57 & 1.33 & 1.06 & 1.47 & 7.61 \\
\hline CV \% & 8.44 & 9.35 & 10.27 & 13.79 & 9.10 & 9.65 \\
\hline
\end{tabular}

V1-IRH 103, V2- IRH 111, N1- 100\% RDF (Inorganic), N2-75\% RDF (Organic + inorganic), N3-100\% RDF (Organic + inorganic), N4- 150\% RDF (Organic + inorganic), N5- 150\% RDF (Inorganic) 
Table.3 Effect of different integrated nutrient management on available NPK after harvest

\begin{tabular}{|c|c|c|c|}
\hline Treatment & Available N $\left(\mathrm{kg} \mathrm{ha}^{-1}\right)$ & Available $P\left(\mathrm{~kg} \mathrm{ha}^{-1}\right)$ & Available K $\left(\mathrm{kg} \mathrm{ha}^{-1}\right)$ \\
\hline \multicolumn{4}{|c|}{ Varieties } \\
\hline V1 & 267.84 & 21.94 & 222.58 \\
\hline $\mathbf{V} 2$ & 270.21 & 21.27 & 221.59 \\
\hline SEm \pm & 3.81 & 0.63 & 3.70 \\
\hline CD at $5 \%$ & NS & NS & NS \\
\hline CV \% & 5.48 & 11.23 & 6.45 \\
\hline \multicolumn{4}{|c|}{ Integrated Nutrient Management } \\
\hline N1 & 267.12 & 21.34 & 220.25 \\
\hline $\mathbf{N 2}$ & 258.70 & 18.38 & 214.43 \\
\hline $\mathbf{N 3}$ & 264.52 & 20.20 & 217.33 \\
\hline N4 & 271.57 & 23.13 & 226.78 \\
\hline N5 & 283.23 & 24.98 & 231.62 \\
\hline SEm \pm & 5.42 & 1.17 & 2.44 \\
\hline CD at $5 \%$ & NS & 3.53 & 7.36 \\
\hline CV \% & 5.94 & 13.23 & 2.68 \\
\hline
\end{tabular}

V1-IRH 103, V2- IRH 111, N1- 100\% RDF (Inorganic), N2-75\% RDF (Organic + inorganic), N3-100\% RDF (Organic + inorganic), N4- 150\% RDF (Organic + inorganic), N5- 150\% RDF (Inorganic)

Table.4 Effect of integrated nutrient management on physic-chemical properties in soil after harvest

\begin{tabular}{|l|c|c|c|c|}
\hline \multirow{2}{*}{ Treatment } & \multicolumn{3}{|c|}{ Physico-chemical properties } \\
\hline & \multicolumn{3}{|c|}{ OC } & \multicolumn{2}{|c|}{$\mathbf{p H}$} & EC & BD \\
\hline V1 & 0.60 & 6.21 & 0.03 & 1.37 \\
\hline V2 & 0.59 & 6.25 & 0.03 & 1.40 \\
\hline SEm \pm & 0.03 & 0.02 & 0.001 & 0.005 \\
\hline CD at 5\% & NS & NS & NS & NS \\
\hline CV \% & 21.29 & 1.44 & 10.54 & 7.23 \\
\hline & \multicolumn{2}{|c|}{ Integrated Nutrient Management } & \\
\hline N1 & 0.60 & 6.23 & 0.03 & 1.40 \\
\hline N2 & 0.66 & 6.05 & 0.02 & 1.30 \\
\hline N3 & 0.62 & 6.15 & 0.02 & 1.36 \\
\hline N4 & 0.56 & 6.31 & 0.04 & 1.41 \\
\hline N5 & 0.53 & 6.38 & 0.04 & 1.45 \\
\hline SEm \pm & 0.03 & 0.03 & 0.002 & 0.013 \\
\hline CD at 5\% & NS & 0.11 & 0.007 & 0.04 \\
\hline CV \% & 16.84 & 1.34 & 10.54 & 7.23 \\
\hline V1 & & & & \\
\hline
\end{tabular}

V1-IRH 103, V2- IRH 111, N1- 100\% RDF (Inorganic), N2-75\% RDF (Organic + inorganic), N3-100\% RDF (Organic + inorganic), N4- 150\% RDF (Organic + inorganic), N5- 150\% RDF (Inorganic) 
Table.5 Effect of integrated nutrient management on grain yield, straw yield and harvest index of hybrid rice

\begin{tabular}{|l|c|c|c|}
\hline Treatment & $\begin{array}{c}\text { Grain yield } \\
\left(\mathbf{q} \mathbf{~ h a}^{-\mathbf{1}}\right)\end{array}$ & $\begin{array}{c}\text { Straw yield } \\
\left(\mathbf{q} \mathbf{~ h a}^{-\mathbf{1}}\right)\end{array}$ & $\begin{array}{c}\text { Harvest index } \\
(\mathbf{\%})\end{array}$ \\
\hline V1 & \multicolumn{2}{|c|}{ Varieties } \\
\hline V2 & 46.64 & 57.14 & 44.97 \\
\hline SEm \pm & 38.89 & 49.44 & 43.98 \\
\hline CD at 5\% & 0.50 & 0.77 & 0.22 \\
\hline CV \% & 3.60 & 5.03 & NS \\
\hline & 4.10 & 5.58 & 1.89 \\
\hline N1 & Integrated Nutrient Management & \\
\hline N2 & 40.74 & 51.41 & 44.15 \\
\hline N3 & 42.18 & 51.25 & 45.02 \\
\hline N4 & 40.39 & 51.26 & 44.04 \\
\hline N5 & 42.12 & 51.61 & 44.90 \\
\hline SEm \pm & 48.42 & 60.92 & 0.40 \\
\hline CD at 5\% & 1.19 & 1.75 & NS \\
\hline CV \% & 3.60 & 5.30 & 2.22 \\
\hline
\end{tabular}

V1-IRH 103, V2- IRH 111, N1- 100\% RDF (Inorganic), N2-75\% RDF (Organic + inorganic), N3-100\% RDF (Organic + inorganic), N4- 150\% RDF (Organic + inorganic), N5- 150\% RDF (Inorganic)

Table.6 Effect of integrated nutrient management on economics of hybrid rice

\begin{tabular}{|l|c|c|c|c|}
\hline Treatment & $\begin{array}{c}\text { Cost of cultivation } \\
\text { (Rs.) }\end{array}$ & Gross income(Rs.) & $\begin{array}{c}\text { Net income } \\
\text { (Rs.) }\end{array}$ & B:C ratio \\
\hline & \multicolumn{4}{|c|}{ Varieties } \\
\hline V1 & 40236 & 116600 & 76363 & 2.90 \\
\hline V2 & 40236 & 97233 & 56997 & 2.41 \\
\hline SEm \pm & - & 1243 & 1243 & 0.03 \\
\hline CD at 5\% & - & 8147 & 8147 & 0.22 \\
\hline CV \% & $-\quad 4.51$ & 7.72 & 5.05 \\
\hline & \multicolumn{2}{|c}{ Integrated Nutrient Management } \\
\hline N1 & 39728 & 101833 & 62105 & 2.56 \\
\hline N2 & 39412 & 105437 & 66025 & 2.67 \\
\hline N3 & 40942 & 100958 & 60016 & 2.47 \\
\hline N4 & 38312 & 105302 & 66990 & 2.76 \\
\hline N5 & 42787 & 121052 & 78265 & 2.83 \\
\hline SEm \pm & - & 2972 & 2972 & 0.08 \\
\hline CD at 5\% & - & 8987 & 8987 & 0.23 \\
\hline CV \% & - & 6.81 & 10.92 & 6.94 \\
\hline V1
\end{tabular}

V1-IRH 103, V2- IRH 111, N1- 100\% RDF (Inorganic), N2-75\% RDF (Organic + inorganic), N3-100\% RDF (Organic + inorganic), N4- 150\% RDF (Organic + inorganic), N5- 150\% RDF (Inorganic) 


\section{Available NPK in soil after harvest}

The data on available $\mathrm{N}, \mathrm{P}$ and $\mathrm{K}$ in soil as influenced by different treatment as presented in Table 3. The data reveals that there was no significant difference was found in available NPK in soil after harvested in variety V1 (IRH 103) and V2 (IRH 111) but in case of different nutrient management practices treatment N5 (150\% RDF through inorganic) observed significantly highest available NPK in after harvested soil which was at par with N4 (150\% RDF through organic + inorganic) treatment and lowest was noticed in treatment N2 (75\% RDF through organic + inorganic). Similar result observed by Mahmud et al., (2016) observed that the maximum total nitrogen, available phosphorus, and exchangeable potassium, content after in the soil was observed in vermicompost $4 \mathrm{t} \mathrm{ha}^{-1}$ with 150-24-99-18 kg N, P, K, S ha ${ }^{-1}$.

\section{OC, pH, EC and BD in soil after harvest}

$\mathrm{OC}, \mathrm{pH}, \mathrm{EC}$ and bulk density after harvest in soil is presented in Table 4 . The data reveals that the available $\mathrm{OC}, \mathrm{pH}, \mathrm{EC}$ and $\mathrm{BD}$ were found no significant differences in soil after harvest in both variety V1 (IRH 103) and V2 (IRH 111) but in case of different nutrient management practices treatment N5 (150\% $\mathrm{RDF}$ through inorganic) observed significantly highest available $\mathrm{pH}, \mathrm{EC}$ and bulk density in soil after harvest but it was observed at par with treatment N4 (150\% RDF through + inorganic) and lowest soil physico- chemical was noticed in treatment $\mathrm{N} 2$ (75\% RDF through organic + inorganic). The available organic carbon was found no significant effect among all the treatment but numerically highest $O C$ was noticed in treatment $\mathrm{N} 2$ (75\% RDF organic + inorganic) and lowest OC was observed in treatment N5 (150\% RDF through inorganic). Similar result reported by Harikesh et al., (2017) reported that the regular incorporation of organic manures - FYM, vermicompost increased organic carbon content by $0.10-0.15$ per cent. Harikesh et al., (2017) also reported that continuous application of various organic manures such as FYM + vermicompost and inorganic fertilizers resulted in decline of soil pH. Chettri et al., (2017) also observed that the highest $\mathrm{pH}(7.40)$ and $\mathrm{EC}\left(0.20 \mathrm{dsm} \mathrm{m}^{-1}\right)$ of post harvest soil was recorded from $100 \%$ recommended NPK as chemical fertilizer.

\section{Grain and straw yield}

Table 5 reveals that variety V1 (IRH 103) recorded significantly highest grain and straw yield than the V2 (IRH 111) and in nutrient management, N5 (150\% RDF through inorganic) registered significantly higher grain and straw yield among all the treatment. Harvest index shows non significant effect due to variety and different nutrient management.

\section{Gross return}

The responses of various treatments under rice on economics parameter are presented in Table 6. The data reveals that the V1 (IRH 103) recorded significantly higher gross return than V2 (IRH 111). However, in different nutrient management practices treatment N5 (150\% RDF through inorganic) noticed significantly highest gross return and lowest gross return was observed in N3 (100\% RDF through organic + inorganic) during experimentation.

\section{Net returns}

The data on gross return presented in Table 6 . The data reveals that the V1 (IRH 103) was recorded significantly higher net return than V2 (IRH 111) and in different nutrient management practices treatment N5 (150\% RDF through inorganic) was found significantly highest net return and lowest net 
return was observed in N3 (100\% RDF through organic + inorganic) treatment among all treatment.

\section{B: C ratio}

The data reveals that the V1 (IRH 103) was recorded significantly higher net return than V2 (IRH 111) and in different nutrient management practices treatment N5 (150\% $\mathrm{RDF}$ through inorganic) was found significantly highest $\mathrm{B}$ : $\mathrm{C}$ ratio but it was found at par with $\mathrm{N} 2(75 \% \mathrm{RDF}$ through organic + inorganic) and N4 (150\% RDF through organic + inorganic), and lowest $\mathrm{BC}$ ratio was observed in $\mathrm{N} 3100 \% \mathrm{RDF}$ through organic + inorganic) during the one year experimentation. Similar result found by Usman et al., (2003) reveals that highest value of benefit cost ratio was observed in case of combined application of organic manure in form of poultry manure @ $20 \mathrm{t} \mathrm{ha}^{-1}$ followed by application of FYM @ $20 \mathrm{t} \mathrm{ha}^{-1}$ along with same amount of mineral fertilizers. Tiwari et al., (2017) also recorded the maximum gross and net returns and the lowest cost of cultivation under $50 \%$ recommended NPK through fertilizer $+50 \%$ $\mathrm{N}$ (FYM) than other treatments.

\section{References}

Arancon, N.Q., Edwards C.A. and Bierman, P. 2006. Influences of vermicomposts on field strawberries: Part 2. Effects on soil microbiological and chemical properties. Bioresour. Technol., 97: 831-840.

Chettri, P., Maiti, D. and Rizal, B. 2017. Studies on soil properties as affected by integrated nutrient management practice in different cultivars of local scented rice (Oryza sativa L.) Journal of Crop and Weed, 13(2): 25-29.

FAOSTAT. 2014. Area, Production and Yield of Maize, Rice and Wheat. Accessed
June 15, 2015. http://faostat3.fao.org/browse/Q/*/E.

Harikesh., Ali, A., Singh, G., Kumar, S., Shivam., Yadav, R. P., Tiwari, A., Kumar, A. and Yadav, A. 2017. Effect of integrated nutrient management and plant geometry on soil properties and availability of nutrients under SRI technique of rice. Journal of Pharmacognosy and Phytochemistry, 6(5): 86-89.

Jagadeeswari, P.V. and Kumaraswamy K. 2000. Long- term effects of manure fertilizer schedules on the yield of and nutrient uptake by rice crop in a permanent manurial experiment. J. Indian Soc. Soil Sci., 48(4): 833-836.

Kumar, V., Prasad, R. K., Suman, S. N. and Tiwari, S. 2011. Integrated nutrient management for better soil fertility and rice productivity. Oryza, 58(4): 335338.

Mahmud, A. J., Shamsuddoha, A. T. M., Issak, M., Haque, M. N. and Achakzai, A. K. K. 2016. Effect of Vermicompost and Chemical fertilizer on the nutrient content in Rice grain, straw and post harvest soil. Middle-east Journal of Scientific Research, 24(2): 437-444.

Ministory of agriculture \& farmers welfare, 2016. www.agricoop.com.

Paul, T., Bisht, P. S., Pandey, P. C., Singh, D. K. and Roy, S. 2013. Rice productivity and soil fertility as influenced by nutrient management in rice (Oryza sativa)-wheat (Triticum aestivum) cropping system. Indian Journal of Agronomy, 58 (4): 495-499.

Peng, S., Yang, J., Garcia, F. V., Laza, R.C., Sanico, A. L., and Visperas, R. M. 2002. Physiological bases of heterosis and crop management strategies for hybrid rice in the tropics. Paper at the $4^{\text {th }}$ Int. Symposium on Hybrid rice, 1417 May 2002, Hanoi, Vietnam. P 26.

Singh, T., Shivay, Y. S. and Singh, S. 2004. 
Effect of date of transplanting and nitrogen on productivity and nitrogen use indices in hybrid and non hybrid aromatic rice. Acta Agronomica Hungarica, 52(3): 245-252.

Tiwari, A., Tiwari, A., Singh, N. B. and Kumar, A. 2017. Effect of Integrated nutrient management on soil properties, yield and economics of rice (Oryza sativa L.). Research in Environment and Life Sciences, 10(7): 640-644.

Usman, M., Ullah, E., Warriach, E. A., Farooq, M. and Liaqat, A. 2003. Effect of Organic and Inorganic Manures on
Growth and Yield of Rice Variety "Basmati-2000". International Journal of Agriculture and Biology, 5(4): 481483.

Virmani, S. S. 1996. Hybrid rice. Adv. Agron., 57: 377-462.

Yuan, L. P. 1996. Hybrid Rice Breeding in China, In: S. S. Virmani, et al., Eds., Advances in Hybrid Rice Technology, Proceeding of 3rd International Symposium on Hybrid Rice, Hyderabad, 14- 16 November 1996:2733.

\section{How to cite this article:}

Thalesh Kumar, A. K. Thakur, Sandeep Kumar, Om Prakash Bhaskar and Bhupendra Kumar. 2020. Effect of Integrated Nutrient Management on Nutrient Uptake, Physico-Chemical Properties of Soil and Economics of Hybrid Rice. Int.J.Curr.Microbiol.App.Sci. 9(10): 11671175. doi: https://doi.org/10.20546/ijcmas.2020.910.140 